\title{
Stereospecific obtention of building blocks for $\beta$ - hydroxycarboxylic acids: D- and L-arabinose approach
}

\section{Fábio da Paixão Soares and Bogdan Doboszewski}

Departamento de Química, Universidade Federal Rural de Pernambuco,52171-900 Recife, PE, Brasil

\author{
bdoboszewski@hotmail.com
}

Keywords: hydroxycarboxylic acid, arabinose, stereospecific

\section{INTRODUCTION}

The Lipids A, constituents of the lipopolysaccharides from the outer membrane of Gram-negative bacteria are highly toxic and potentially lethal via overactivation of the immune system. ${ }^{1,2}$ However, in the case of cancer or AIDS patients, immune activation can be beneficial. One can therefore consider analogs of the Lipids $A$ as potential immunity boosters without their toxic character. Since $\beta$-hydroxycarboxilic acids are one of the components of Lipids $A$, their general synthesis in chiral forms for further work is desired. Reported here is a stereospecific synthesis of the chiral building blocks 1 and 2 which permit obtention of the $\beta$-hydroxycarboxylic acids of variable moiety $R$.<smiles>[R]C[C@@H](O)[C@H](O)CC(=O)O</smiles>

1: from D-Ara<smiles>[R]C[C@H](O)C[C@@H](O)C(=O)O</smiles>

2: from L-Ara

\section{RESULTS AND DISCUSSION}

Our approach takes advantage of availability of Dand L-arabinose, their reasonable price and their stereochemical constitution. In its furanoses form, e.g. 3, D-arabinose exposes a free $-\mathrm{OH}$ group amenable for removal. Attempts to apply Bartontype deoxygenation to get $\mathbf{1}$ starting from either $\mathbf{3}$ or the lyxo compound 5 (obtained from $\mathbf{3}$ via oxidation and reduction) proceeded in low yields (ca 25\%). Excellent yields however were obtained during treatment of 3-O-triflate derived from 4 with $\mathrm{LiHBEt}_{3}$.<smiles>[R]C[C@H]1O[C@@H]2OC(C)(C)O[C@H]1[C@H]2C</smiles>

$\mathrm{HO}$

$3 \mathrm{R}=-\mathrm{SitBuPh} 2$<smiles>[R]CC1O[C@@H]2OC(C)(C)O[C@@H]1[C@H]2O</smiles>

$4 \mathrm{R}=-\mathrm{SitBuPh}$
$4 \underset{2 . \mathrm{LiHBEt}_{3}}{\stackrel{\text { 1. } \mathrm{Tf}_{2} \mathrm{O}, \mathrm{Py}}{\longrightarrow}}$<smiles>[R]OC</smiles>

$6 \mathrm{R}=-\mathrm{SitBuPh} 2$

85-90\% for two steps

Scheme 1. Exceptionally efficient deoxygenation in $\mathbf{4}$ via substitution using "superhydride" $\mathrm{LiHBEt}_{3}$

The procedure shown above was applied to 5-O tbutyldiphenylsilyl-1,2-isopropylidenearabinofuranose to furnish enantiomeric compound 2.

Attempts are underway to transform 7 to 1 via a modified Wolff-Kishner reaction.<smiles>[R]C[C@H]1O[C@@H]2OC(C)(C)O[C@H]1C2=N[SiH3]</smiles>

$7 \mathrm{R}=-\mathrm{SitBuPh} 2$

\section{CONCLUSION}

Efficient chiral pool stereospecific procedure was devised to obtain building blocks for synthesis of $\beta$ hydroxycarboxylic acids.

\section{ACKNOWLEDGEMENTS}

Post-Graduation Program in Chemistry at the UFRPE is acknowledged for a scholarship for FDPS.

\section{REFERENCES}

${ }^{1}$ Carbohydrate-based drug discovery. Wong, C.-H., ed. Wiley-VCH, 2003.

${ }^{2}$ Carbohydrates in chemistry and biology. Ernst, B.; Hart, G.W.; Sinaÿ, P., eds. Wiley-VCH, 2000. 